\title{
GLAUBER ROCHA, intérprete farol da imaginação
}

Marcos Cezar Botelho de souza (UNEB)

Para a Piaba Bailarina, que me acolheu em sua biblioteca

Poucas questôes filosóficas sulcaram tanto a vocação do pensamento moderno brasileiro quanto a ideia de nação. Embora essa não tenha sido uma demanda privativa da elite intelectual brasileira, mas uma sobredeterminação presente nas produçóes simbólicas das sociedades pós-coloniais na América Latina, a nacionalidade, campeada na ontológica falta das especificidades unívocas das sociedades oriundas do processo de expansão colonialista no Ocidente, protagonizou grande parte dos discursos culturais na América Latina ao longo do século 20. A própria repetição compulsiva das interpretaçôes da nossa formação social indicia a necessidade de se preencher esse significante disponível, paradoxalmente faltante e excessivo, que é a nação e seus corolários satelitários. Com efeito, os marcadores temporais dessa demanda trazem as marcas da racionalidade que cada roçado científico escolheu como lentes de aumento para iluminar e completar os termos irredutíveis que compóem o sintagma "identidade nacional". Como os recortes que cada ciência formal efetua no tempo inapreensível da nação são arbitrários, há sempre temporalidades que escapam pelas bordas científicas e encontram, sobretudo nas revisōes da "contemporaneidade" - este outro termo-ônibus problemático mas inescapável - outras versóes, não menos arbitrárias, nas expressôes artísticas que narraram e ainda compóem nosso imaginário. Assim, costuma-se iniciar a leitura da narrativa da naçấo no Brasil com a formaçáo discursiva do Romantismo e 
seus topoi extraídos do descomedimento discursivo da história franqueado à fabulação literária: o sentimento nativista de uma natureza alentada, a presença ausente dos índios e afrodescendentes, os corpos que emanam as "cores locais", a invenção de passados míticos pós-Independência, as negociaçóes das autonomias política e cultural, os lugares simbólicos e as imagens do folk nas culturas popular e erudita etc. Nas passagens dos mitos ao logos, foram retiradas, desses espaços e tempos situados no passado, as representaçóes que preencheriam aquilo que faltava: uma unidade identitária à realidade múltipla e cambiante do presente. Em todos os casos, destaca-se o empenho em desentranhar do passado os motivos que elucidassem os porquês da formação brasileira no presente, "iluminando" seus desvãos e, num limite questionável, um núcleo psicológico da "alma brasileira", esse espectro que ainda ronda o reino do pensamento e das artes no Brasil. Tal missão de preenchimento por meio da natureza e história matrizes da nação ocupou, durante décadas, a "ilustração à brasileira" que pelejou incansavelmente com representaçóes que debelassem a irredutibilidade das identidades culturais e, por fim, abonassem, nos estratos imaginários, a identidade nacional, conferindo uma coesão ontológica à vida social. Essa grande narrativa da nação foi contada por pensadores, escritores, pintores, historiadores, poetas e intelectuais de diversos matizes teóricos e estéticos, irmanados, às vezes, por uma mesma epistême, mas com orientaçóes ideológicas diversas. Em cada passo e gesto interpretativo, camadas discursivas foram acrescidas e superpostas, tornando o construto da nação um palimpsesto espesso, opaco, borrado, mas sempre disponível ao pensamento. Como a literatura, também o ensaísmo e o cinema foram/são férteis engenhos de imagens, enunciados e personagens-conceituais que compóem - e, em alguns casos, até mesmo rasuraram - o temário dessa narração compulsória da identidade nacional.

Como se sabe, a literatura foi a ponta-de-lança dessa invenção identitária. As missóes das letras trouxeram inscritas, já em suas cenas inaugurais, as ambivalências típicas da construção nacional: já que a própria nação era também uma ideia importada, precisando, portanto, ser costurada a partir de "fora" às exigências "locais", foi necessário encontrar outros encaixes entre a cultura popular, propriamente dita, e os novos aparatos da modernidade cosmopolita e massiva. Esse movimento esquivo e característico das culturas periféricas, nas quais a modernização e a modernidade parecem sempre inacabadas, convivendo com descompassos e arcaísmos eternos de toda ordem, conferiu à nossa gaia ciência artística uma singularidade criativa marcada pelo imbricamento de elementos e temporalidades "externos e internos" fecundados pelos suplementos que os arrastóes de ideias deslocadas de seus lugares originários proporcionavam. Essa dialética, por exemplo, está no cerne dos debates sobre o cinema brasileiro desde a fase heroica do Cinema Novo: 
o impasse permanente entre a vocação histórica dos nossos filmes no trato da difícil realidade do país, que tem como princípio o empenho ético de inventar uma estética própria, ou se constituir como parte de uma cadeia da indústria do entretenimento "global" do cinema de gênero "hollywoodiano".

O objetivo principal deste roteiro é comentar algumas passagens de filmes e posicionamentos do cineasta e pensador Glauber Rocha, como fachos de uma obra farol impelida por uma hermenêutica da cultura brasileira. Como diz Ivana Bentes em Cartas ao Mundo, já é hora de tirar Glauber do 'gueto' do cinema e inseri-lo na "história da cultura e do pensamento contemporâneos, dos quais seu cinema faz parte. O que já podia ser vislumbrado nos filmes, esse Glauber pensador, estrategista, teórico da cultura e do cinema, ganha com a leitura dos seus escritos maior visibilidade" (BENTES, 1997, p. 09).

\section{Um rolezinho anos faróis da interpretação}

Para Antonio Candido, em pleno processo de instalação da modernidade nos trópicos, muitos autores, divididos entre "o ímã da literatura e a tendência sociológica", buscavam sínteses e explicaçóes que redefinissem "a nossa cultura à luz de uma avaliação nova dos seus fatores". Foram esses primeiros intérpretes que procuraram delinear as feições da nação, os embaraços e as tramas de suas histórias, legando um corpus híbrido de projeçôes no qual se "combinam com felicidade maior ou menor a imaginação e a observação, a ciência e a arte - que constitui o traço mais característico do nosso pensamento" (CANDIDO, 1965, p. 157). Tais obras ${ }^{1}$, como sugere a metáfora náutica de Silviano Santiago, nos serviram de

farol (e não de espelho, como quer uma teoria mimética apegada à relação estreita entre realidade e discurso). Com a sua ajuda e facho de luz é que temos caminhado, pois eles iluminam não só a vasta e multifacetada região em que vivemos, como também a nós, habitantes que dela somos, alertando-nos tanto para os acertos quanto os desacertos administrativos, tanto para o sentido do progresso moral quanto para o precipício dos atrasos irremediáveis. (SANTIAGO, 2002, p. XV).

Podemos dizer que esses faróis da formação cultural do país não apenas forneceram chaves de análise e interpretação às ciências sociais e às artes brasileiras, mas inventaram, no próprio círculo interpretativo de suas intuiçôes, esse objeto não-identificado que é a nação brasileira. Essa imagem oscilatória entre o claro e escuro nas interpretaçóes das da nação ressurge em outra visão do farol, presente na letra da canção 12 segundos de obs- 
curidad, de outro intérprete das contradiçóes latino-americanas, o compositor uruguaio Jorge Drexler, que diz: "Un faro quieto nada seria/ Guía, mientras no deje de girar/ no es la luz lo que importa en verdad/ son los 12 segundos de oscuridad". 2 A representação dos 12 segundos de obscuridade, ou seja, da escuridão como contraparte inevitável da luminosidade, entre o balanço do brilho das intuiçóes e o eclipse dos impasses, nos fornece uma chave de leitura das interpretaçóes do país, que giram, em tempos e lentes variáveis, entre a ênfase na negativa obscuridade e na positiva luminosidade das características nacionais. É claro que essas ambivalências aparecem comparativamente obra a obra, mas, muitas vezes, também podem estar inscritas em uma mesma obra e no olhar de um mesmo autor, bastando lembrar os deslizamentos de uma visão pessimista da obscuridade do país a outra mais luminosamente nuançada, como no caso de Euclides da Cunha em Os Sertóes; ou no ambivalente "Homem Cordial", de Sérgio Buarque de Holanda, personagem conceitual que "ilumina” tanto a afabilidade do convívio "pessoal", assim como a permanência "obscurantista e pessoalista" do mandonismo patriarcal das relaçôes sociais no Brasil.

\section{Glauber Rocha na avant-garde da província planetária}

As memórias afetivas de quem viveu o clima cultural do período heroico do Cinema Novo grifam o quanto seus filmes lançaram refletores imprevistos e desconcertantes sobre as desigualdades e a fome brasileiras e o quanto posicionamentos ideológicos e estéticos de seus autores foram capazes de iluminar lugares até então mantidos no espaço off do nosso imaginário colonizado. Hoje, contudo, não há como não reconhecer, a despeito do esforço louvável e da grandeza dessa geração, que os tempos mudaram e o quanto suas lentes não foram capazes de fazer fulgurar outras expressões políticas, notadamente aquelas mais refratárias às pautas da luta de classes, as quais permaneceram nas zonas brumosas e obscuras de seus faróis. Em Barravento (1962), de Glauber Rocha, somente para ficar em um exemplo notável, o acento na conscientização ideológica da luta de classes e a invenção do "novo homem do povo" oposto à classe dominante sequestra e/ou lança de forma ambivalente o Candomblé ao plano das alienaçóes populares e não como um dos principais lócus da memória e resistência da cultura afro-brasileira. Não se trata de reviver aqui as velhas "patrulhas ideológicas", como os novos cururus da moralidade no admirável mundo novo têm coaxado por aí. Rememorando o atualíssimo Aldous Huxley (2014), é bom lembrar que em matéria de ética artística não é politicamente produtivo, de modo algum, pôr-se a remoer ressentidamente as más avaliaçôes políticas e as aporias conceituais típicas de outros momentos. Espojar-se na 
lama, diz Huxley, não é a melhor maneira de ficar limpo. E parafraseando uma figura cara à geraçáo cinemanovista, o gigantesco Jean-Paul Sartre (2006), que se equivocou feio muitas vezes em matéria de política, mas acertou em cheio em filosofia e literatura, mesmo que o passar do tempo contradiga as certezas que o artista engajado teve em dada época (o que sempre acontece), isso não é motivo para se refutar por inteiro seu pensamento e obras, colocando em primeiro plano apenas seus julgamentos políticos, desvarios idealistas e equívocos ideológicos, mas, sim, vendo nelas uma vontade decidida - parte de uma cosmovisão contingencial e envolvimento com as inquietaçóes do mundo imediato -, assim como um empenho por ter se engajado nas meias-certezas do seu tempo. Ou seja, são justamente as criações intelectuais mais duradouras aquelas passíveis de revisão constante e de terem reavaliados, a posteriori, os limites de suas apostas, segundo a ótica contemporânea, os impasses sintomáticos de uma dada episteme e um modo de pensamento, assim como a permanência de seus acertos.

Embora o lema dos cinemanovistas - "uma câmera na mão, uma ideia na cabeça" - já tenha se tornado praticamente um adágio, a ponto de ser usado em campanha publicitária de uma poderosa operadora de telefonia global, as reverberaçóes punks de sua liçấo estilo Do It Yourself ainda podem ser vistas ativamente nos "cinema das periferias" e nas produçôes dos coletivos sociais minoritários. Esses "cinemas de guerrilha" se apropriam de novos suportes tecnológicos e, com ideias de autonomia nas cabeças, como fazia o Cinema Novo, procuram agenciar imagens que se esquivam do miserabilismo enlatado pelo espetáculo banal e paternalista predominante na midiascape. Situados nas margens nacionais e fora dos sistemas formais de produçáo, esses coletivos continuam, portanto, a mesma missão que transforma a precariedade em ação coletiva e a tarefa de interpretação cotidiana do Brasil, requisitos fundamentais dos grandes artistas e intelectuais "profissionais" do Modernismo e do Cinema Novo. Silviano Santiago, que considera Glauber e Hélio Oiticica os maiores artífices da geração de 1960, percebeu a distribuição dessa renda simbólica legada pelos atrevidos intérpretes modernistas da nação nas novas políticas da cidadania contemporânea, nas Jornadas de Junho de ativistas fora-dos-eixos, nas reivindicaçóes de estudantes universitários e secundaristas, nas esquivas dos movimentos hip-hop e da literatura marginal, que tomaram para si a interpretaçáo do passado, do presente e dos destinos do país. Náo se trata, todavia, de novas interpretaçôes ou "novos retratos de questôes antigas", vinho novo em pipa velha, mas, ao contrário, de releituras dissonantes que iluminam pontos-cegos da narrativa nacional e "mudam seu foco, tirando de si mesmas outras fotos", para citar enviesadamente Férrez, outro romancista e intérprete do Brasil contemporâneo. Por conseguinte, não seriam esses cidadãos, por lançarem seus faróis sobre as obscuridades 
da identidade nacional, nossos mais agudos e atualizados intérpretes da nação? Silviano Santiago desmistifica a concepção do intelectual "profissional" como único privilegiado da interpretação nacional, levantando novas indagaçóes:

Durante a nossa penosa e por vezes milagrosa formação educacional e profissional, não seremos todos - cada um - intérpretes do Brasil? Cada um a sua maneira, cada um com suas ideias e formação, cada um com a sua visão de mundo e idiossincrasias familiares, ideológicas e partidárias, cada um de nós não seria um intérprete de nossa nação, um intérprete compulsivo, diletante e pluridisciplinar? [...] Poderemos ser bons torneiros mecânicos ou engenheiros, poderemos ser bons jornalistas ou advogados, poderemos ser bons bancários ou banqueiros, se não formos diletantes que se interessam de corpo e alma por conhecer mais e melhor o modo de agir e de pensar dos brasileiros e dos caminhos da nação? [...] A interpretação do Brasil é, pois, um pacote coletivo de tarefas que cada um de nós traz para sua vida diária, a fim de suplementá-la de modo inteligente e reflexivo. (SANTIAGO, 2009, p. 22).

No que pese a obsolescência de parte considerável de sua agenda político-ideológica, os filmes de Glauber Rocha, que nunca separaram cinema, periferia e política, como fazem os recentes "cinemas de guerrilha", continuam "inatuais", no sentido nietzscheano do termo, perturbadoramente contemporâneos porque intempestivos. Com efeito, seus filmes ainda sacodem percepçóes, provocando nas audiências tanto iluminaçóes profanas quanto um admoestatório mal-estar. As reaçóes geradas por suas obras abertas, às vezes ao nível da repulsa, atingem diretamente as mentes apavoradas com aquilo que ainda não é mesmo velho ou codificado pelas imagens fast-food que o cinema mainstream repete em profusão. $\mathrm{O}$ estranhamento de seus filmes vem, é claro, da concepção glauberiana da linguagem cinematográfica, que manda para o vinagre as normas narrativas da transparência discursiva do cinema clássico, a saber: a continuidade do raccord naturalista, a previsibilidade da teleologia evolutiva do enredo, a luz bem acabada da transparência; as regras de identificação ideológica e anestesiante do drama burguês e "as sequências dó de peito". No que pese a incorporação desses desvios sintáticos e disjuntivos pela dóxa do audiovisual contemporâneo, os filmes de Glauber desafiam a docilidade corporal e perceptiva dos "imbecis que ficam como cachorros dentro d'água no escuro do cinema". ${ }^{4}$ Mesmo que os insultos modernistas às prescriçôes do drama burguês tenham arrefecido com a repetição da "tradição da ruptura", as invençóes de Glauber desafiam a servidão voluntária do olhar dos contentes e produzem as mesmas dissonâncias que as obras escandalosas dos heróis culturais da modernidade, a exemplo de Luigi Pirandello, Picasso, John Cage, Brecht, James Joyce, Jean-Luc Godard, Oswald 
de Andrade, Guimarães Rosa, Jean-Paul Sartre, Mallarmé, entre outros, despertaram nas audiências e leitores.

Quando deixou Vitória da Conquista, ao completar 18 anos, o jovem Glauber Rocha chegou a Salvador - à época chamada de "Cidade da Bahia" - na antecena de um momento cultural particularmente intenso, a avant-garde baiana, que emergiria em fins dos anos 1950, impulsionado por uma plêiade de intelectuais, professores, artistas e agentes culturais com propostas experimentais inéditas entre nós desembarcou na província. Essa caravana de exilados cosmopolitas tinha a missáo de acertar o passo entre o acanhado ambiente soteropolitano e as informaçóes de ponta do alto modernismo internacional. Como expatriados da modernidade tangidos pelos expurgos totalitários na Europa, esses desterrados juntaram seus esforços ao empenho dos jovens artistas e intelectuais nativos na demanda por uma nacionalidade oxigenada pelos ventos da novidade das novas vanguardas artísticas. No nível conjuntural, é bom lembrar que esse "acontecimento" identificado se deu em torno da reinvençáo da Universidade da Bahia, levada a cabo por Edgar Santos, depois reitor da Universidade Federal da Bahia (UFBA), personagem-chave da guinada histórica, a qual alguns mais excedidos chegaram a batizar, com termos que traem as referências classicizantes da então elite mezzo-jeca de Salvador, de "a Renascença Baiana”.

Com consideração política em alta e sob o guarda-chuva desenvolvimentista, Edgar Santos cavou um orçamento para a universidade análogo ao disponível pela prefeitura da capital baiana, além de um opulento patrocínio da Fundação Rockefeller. Contra o conservadorismo regionalista, Edgar Santos, paradoxalmente um filho da elite e da oligarquia locais, foi um grande dínamo da modernização da cultura local, fundando em nível universitário cursos e institutos até então inexistentes no país, em áreas como a dança moderna (com a bailarina e coreógrafa polonesa Yanka Rudska à frente), o teatro experimental (com Eros Martin Gonçalves e uma constelação de professores/consultores, como Gianni Ratto, Ana Edler, Sérgio Cardoso, entre outros, montando Brecht, O’Neil e Tennense Williams na recém fundada Escola de Teatro); e a arquitetura modernista, com a italiana Lina Bo Bardi desenvolvendo estilo arquitetônico que dialogava com a modernidade latino-europeia e os elementos da cultura popular do Nordeste (como o projeto do Museu de Arte Popular do Solar do Unhão, além dos inovadoras cenografias teatrais). Também foi efetiva a cena experimental criada nos Seminários Livres de Música da UFBA, para os quais foram contratados diversos compositores estrangeiros ligados às novas frentes musicais europeias, tais como o dodecafonista alemão Hans Joachim Koellreutter (professor de Tom Jobim), Walter Smetak, Ernest Widmer, Pietro Bastianelli, entre outros. Além disso, houve a fundação do 
CEAO-Centro de Estudos Afro-Orientais, dirigido por Agostinho da Silva, e a abertura do Museu de Arte Moderna, organizado igualmente por Lina Bo Bardi ${ }^{5}$, ambos espaços de extensão da universidade. A criação da UFBA foi simultânea às atividades do Clube de Cinema da Bahia, coordenado por Walter da Silveira, e no qual Glauber Rocha teve participação ativa. As escolas de arte e ciências humanas funcionavam conectadas. Nas escolas de Música, Teatro, Dança e Belas Artes, os componentes curriculares eram franqueados "aos cinéfilos frequentadores do Clube de Cinema", que podiam cursar livremente disciplinas nas escolas mencionadas. Essa transdisciplinaridade, recorda Orlando Senna (apud LEAL, 2008, p. 89), seria "uma marca também do movimento cultural baiano dos anos 1960 como um todo, poetas, pintores, dramaturgos, cineastas se envolviam em projetos comuns o tempo todo e as distintas expressóes artísticas estavam articuladas, enredadas".

Ao analisar os agrupamentos de artistas e intelectuais em meio aos impactos das mudanças materiais das primeiras décadas do século 20 na Europa, Raymond Williams discute, em novas bases teóricas, os modos de articulação e compartilhamento de afinidades estéticas e ideológicas que constituíram as formaçôes de movimentos artísticos, como "a Fração Bloomsbury", assentando o conceito de "estrutura de sentimento". Para Williams, a estruturação de sentimentos partilhados entre agentes culturais diversos torna possível a agregação das diferenças estilísticas em "movimentos artísticos e intelectuais", cujas práticas mentais, em convívio num contexto social favorável, podem ser coordenadas "com as formas de produção e de organização socioeconômica que as estruturam em termos dos sentidos que consignamos à experiência do vivido" (CEVASCO, 2001, p. 97). O conceito de estrutura de sentimento torna-se pertinente à análise da avant-garde baiana, sintagma proposto por Antonio Risério (1995), pois suas expressóes colaborativas estiveram ligadas tanto ao big bang cultural da Universidade Federal da Bahia, quanto impactaram, de forma transversal, nos novos arranjos econômicos e sociais, que alavancaram, no cenário da tardia industrialização nacional, o surgimento de novas profissóes liberais e a reorganização de diferentes atores sociais, a exemplo dos sindicatos e das associaçóes políticas de trabalhadores, das produtoras cinematográficas, de estúdios de gravação profissionais, modernização do parque gráfico e agências de publicidades, entre outros setores da economia cultural. Não seria exagero afirmar que esse ecossistema de efervescência cultural - quando a universidade começou de fato a interferir na vida cultural da cidade - originou o solo dos momentos mais criativamente densos, dois pontos de inflexáo na cultura brasileira dos anos 1960: o Cinema Novo e a Tropicália. As aproximações e diferenças desses movimentos culturais vão além das coincidentes balizas temporais. Há entre eles afinidades e desarmonias 
pontuais respeitáveis, mas ambos compartilharam da mesma "estrutura de sentimentos" que fez emergir

os estrados mais profundos e retoricamente sedimentados da identidade histórica e geográfica, pessoal e coletiva. Os objetivos dos cinemanovistas e dos tropicalistas são bem parecidos, mas o estilo e a estratégia do enfoque mediante o qual são executados são tão distintos que constituem quase duas histórias culturais do Brasil, duas maneiras de fazer crítica da cultura e de construir a perspectiva: existencialmente extrovertida a que leva às provocaçóes do Tropicalismo e vocacionalmente e ideologicamente introvertida a que caracteriza as provocaçóes do Cinema Novo. A base comum consiste em reconhecer como necessária e improcrastinável a fundação (ou a refundição) de uma consciência criticamente internacional, popular e não nacionalista para a cultura brasileira, pouco importa se alta ou baixa. (CIPPOLINI, 2009, p. 109).

Como nada nos devires da história cultural floresce por combustão espontânea, aquela quadra especial da vida baiana foi impulsionada pela emergência, como afirma Antonio Risério (1995), por novas direçôes democráticas aceleradas pelo processo de atualização urbano-industrial em meio aos ventos do nacionalismo e do desenvolvimentismo. Nesse momento, Salvador pôde se levantar da sua endogênia letárgica, e, com toda a sua densidade e singularidade culturais, abrir-se aos influxos transnacionais de informaçóes estéticas "e ainda se preparar para intervir, nacionalmente, sob os signos da modernidade e da radicalidade" (RISÉRIO, 1995, p. 13). Dessa "estrutura de sentimentos", que buscou vencer a província na própria província - ou quando a periferia se pensou mundializada - surgiram e participaram, no mesmo tempo e lugar, além dos mediadores culturais acima lembrados, outros intérpretes do Brasil, como Glauber Rocha, Rogério Duarte, Orlando Senna; os grandes poetas Waly Salomão, Duda Machado, Torquato Neto e José Carlos Capinan; o romancista João Ubaldo Ribeiro e o filósofo da contracultura Luiz Carlos Maciel; músicos e compositores (in) formados nos Seminários Livres de Música, como Tom Zé, Tuzé de Abreu, Alcivando Luz, Caetano Veloso, Gilberto Gil e, correndo por fora, porém dentro desse processo de modernização, Raul Seixas, aluno do Curso de Filosofia da UFBA. Antonio Risério (1995, p. 20) póe na conta dessa estação de ebulição e criatividade, povoada por intervençóes empenhadas em projetos de transformação cultural do país, "a origem última das sublevaçôes que, como o Cinema Novo e a Tropicália, alteraram irreversivelmente a paisagem cultural em nossos alegres tristes trópicos". Orlando Senna, outro grande passageiro desse "fogaréu cultural" e "testemunha ocular dos fatos", como Glauber Rocha o chamou a vida inteira, afirma que 
na virada das décadas 1950/1960 aconteceu uma conjunção, uma soma de acontecimentos raros, que produziu uma energia cultural de alta voltagem em Salvador da Bahia, gerando um movimento que se expandiria pelo País e teria repercussão mundial. Ao mesmo tempo em que emerge a Geração Mapa, saindo da adolescência e balançando vigorosamente a província, e ao mesmo tempo em que a Revolução Cubana ilumina o mundo jovem, materializa-se o projeto da Universidade Federal da Bahia, com um desenho ousado e modernizador. [...] Rapidamente, Salvador da Bahia se transformou no centro cultural mais importante do País, atraindo intelectuais e artistas de toda a parte. [...] Ganhamos, os jovens baianos, novos e brilhantes mestres, inovadores, incendiários, mestres caídos do céu. Cruzaram nossos caminhos, nos deram aulas, conversaram e trocaram idéias conosco estrelas do pensamento do século XX como Sartre, Simone de Beauvoir, Roger Bastide. (apud LEAL, 2008, p. 85).

É preciso notar também que aquilo que hoje costumamos chamar de Cinema Novo foi, sobretudo, uma "ação entre amigos adoradores de livros e filmes" que fizeram a cabeça com a leitura dos grandes intérpretes da cultura nacional e das vanguardas internacionais. Parte desses jovens intelectuais era oriunda da baixa classe-média e partilhava a estrutura de sentimento que cimentava uma "galera cinéfila" e politicamente engajada nos coletivos dos movimentos estudantis e sociais. Além da política na universidade e no CPC - Centros Populares de Cultura da UNE - União Nacional dos Estudantes, havia também as importantes atividades desses jovens pensadores na cena boêmia da cidade, em reunióes regadas a biritas, anfetaminas e utopias nas quais foram tramadas inúmeras estratégias de intervenção nas artes brasileiras.

Sintonizado com os movimentos de descolonização na África e na Ásia e o pensamento político de Jean-Paul Sartre e dos intelectuais africanos reunidos nas Conferências de Bandung, Glauber Rocha passou a se definir como um "cineasta nacionalista do Terceiro Mundo". Entenda-se esse "nacionalismo" não como uma evocação patrioteira a regionalismos ressentidos, a verdeamarelismos de antas e buenos gavióes globais ou a qualquer apego psicologizante ao "caráter nacional brasileiro". Nada a ver, portanto, com um nacionalismo identitário beligerante que, com seu engenhoso modo mágico de fabricar narcisismos em massa, é capaz de recalcar, em nome da casa pátria, outras afiliaçóes bastardas da frátria. Trata-se, com efeito, de um "nacionalismo político pragmático", como define Silviano Santiago ao comentar a concepção nacionalista de Mário de Andrade. Isto é: intelectuais, mas sobretudo homens de ação coletiva, Mário e Glauber tinham um tipo de visada nacional baseada tanto em mediaçóes teóricas eficazes, as interpretaçôes advindas da voracidade pelos livros, quanto em projetos estratégicos de transformação política, econômica, social e cultural que se concretizam, pragmati- 
camente, na esfera pública (no caso de Mário, num só exemplo, a criação do SPHAN, hoje IPHAN; no de Glauber, a EMBRAFILME) -, visando, enfim, enfrentar o descaso político com a memória cultural do país.

A Eztetyca da Fome de Glauber (2004), o manifesto mais importante da cultura brasileira ao lado do Manifesto Antropófago de Oswald de Andrade, foi justamente uma aposta radical, seguindo as intuiçóes Oswald, mas também de Sartre e Frantz Fanon, em Os Condenados da Terra, no sentido de acertar o passo da nossa condiçáo "periférica" com as liçóes do Neorrealismo italiano, das vanguardas soviéticas e da moderna Nouvelle Vague francesa, trazendo à tona, contudo, as singularidades pós-coloniais das cinematografias latino-americanas, as quais puderam escrever de volta aos centros e influenciar, em seguida, cineastas europeus e norte-americanos. A Eztetyca da Fome, em Glauber Rocha, era uma operação metafórica para um estilo excêntrico de se produzir cinema moderno nas periferias atrasadas do mundo. A ideia era modernizar o cinema e transformar as condiçôes adversas de produção em fatores inventivos mais adequados à realidade de um país materialmente pobre. Assim, os filmes "indigentes e esfaimados" dos cinemas novos do Terceiro Mundo tratariam, sem as idealizaçôes paternalistas do colonialismo, a "pobreza, a fome real e metafísica" não apenas no nível temático, mas a partir da materialidade de uma "estética famélica", assumidamente precária e estranha. A estética do filme seria, portanto, um "correlato objetivo" da miséria material. Os vastos conteúdos do subdesenvolvimento nacional confundem-se com e na forma e produzem-se na própria linguagem, a qual não é, na Eztetyca da Fome, mero suporte através do qual se emitem "mensagens sociais". De fato, os próprios modos de representação dos setores marginalizados da nação intensificariam os choques imagéticos da precariedade real sobre as audiências "alienadas e anestesiadas pelo espetáculo de nossa miséria". Assim, a refração (do latim refrigere, refletir e quebrar) no interior da linguagem, resultante do rompimento com os códigos estabelecidos da representação do real, correspondia aos confrontos sígnicos no interior da própria luta de classes. Desmontar as maneiras usuais de representar o colonizado significava, portanto, descolonizar o olhar, tanto do colonizado quanto do colonizador, para chegar à descolonização política e cultural. A "deficiência estrutural" e a "feiura estética" deixavam de se colocar, consequentemente, como obstáculos e eram assumidas como corpora constituintes da obra, definindo a imanência, a composição e a potência da expressão. Isso porque, para Glauber, se a fome material (leia-se o termo como metáfora de todo o corolário do atraso estrutural) era "o sintoma" daquilo que os discursos eufóricos da nação recalcavam, a "fome metafísica" vinha do próprio "inconsciente da sociedade brasileira". Essa vontade de restabelecer, em chave pós-colonial, um "nacionalismo cosmopolita" que aquilatasse pelas margens 
as analogias entre o pensamento, a cultura vernacular e as vanguardas metropolitanas faz de Glauber Rocha um intérprete herdeiro do legado literário modernista no cinema brasileiro. Cacá Diegues asseverou, certa vez, que a maior influência cultural do Cinema Novo foi a literatura brasileira e não tanto os cineastas nacionais ou estrangeiros. De fato, já se tornou um lugar-comum afirmar que o Cinema Novo achou no modernismo, em Mário, Oswald e Carlos Drummond de Andrade, entre outros, suas principais especialidades estéticas e, no Romance Social de 30 (Graciliano Ramos, Jorge Amado, José Lins do Rego etc.), os enunciados imagéticos que falavam mais abertamente da realidade social do país. $\mathrm{Na}$ releitura desse legado das artes modernistas, o Cinema Novo implantou, entre nós, uma atitude diferencial e inédita de contato dos filmes com a literatura: suas películas entraram em conversação com os textos literários, mas superaram a mera transposiçáo literal - ou o simples aproveitamento do enredo pronto - e atualizaram as matérias temáticas das obras literárias com o suplemento das pautas atualizadas.

Para Glauber Rocha, a cultura popular nordestina não era um lugar no qual se pudesse esquadrinhar a pureza intocada da alma nacional, reservatório de seres exóticos a serem conscientizado com didatismo e zelo ideológico, segundo os pressupostos do nacional-populismo e das patrulhas ideológicas de esquerda ou direita. O cineasta, ao contrário, foi buscar nas formas culturais populares o que estas tinham de mais inovador no plano estético, formas complexas e dinâmicas, muitas vezes conservadoras, é fato, mas não reacionárias, que acompanham e incorporam a cultura massiva, tanto quanto as experiências modernistas. Glauber reescreveu, assim, a estrutura mítica dos cordéis - o eterno embate entre o bem e o mal, por exemplo -, revestindo tal maniqueísmo com uma espessura dramática capaz de tornar os heroicos personagens esquemáticos retirados do elenco popular em figuras que enfrentam dilemas existenciais e éticos de grande densidade política e subjetiva. Em um nível ideológico, portanto, Glauber injeta na tradiçáo aparentemente estabilizada do cordel, digamos assim, uma negatividade revolucionária, enquadrada pelos marxismos new left no pensamento artístico brasileiro da época. Reverberando Marilena Chauí (1986), podemos dizer que seus diálogos com a cultura popular do Nordeste investem nos focos da crise, resistência e superaçáo do conservadorismo popular, transformando a potência das batalhas do cordel nordestino, por exemplo, em figuraçóes de lutas sociais contra o conformismo. A façanha artística, por exemplo, de um par como Oswald de Andrade-Glauber Rocha "parece ter sido o encontro de um difícil ponto de união entre uma linguagem extremamente inventiva do ponto de vista formal e a tematização de problemas sociais que são a vergonha desse país”. E Pascoal Farinaccio (2012, p. 11) completa, acertando na mosca: "a famosa frase 
de Maiakóvski - 'sem forma revolucionária não há arte revolucionária’ - cai como uma luva para a produção artística de ambos. Oswald e Glauber foram exímios criadores de novas linguagens e não é exagero nenhum afirmar que a compreensão do que fosse literatura e cinema precisou ser modificada substancialmente após suas intervençôes, sob pena de a interpretação cair na mais absoluta irrelevância”.

\section{Os sertôes do Carandiru e a violência cármica da nação}

Naquele contexto dos anos de 1960, Glauber retomava e amplificava Euclides da Cunha em seu impulso persistente e agonístico de modernizaçáo para o Brasil, que traçasse outros destinos para a naçáo. Não por acaso, Glauber foi chamado por Hélio Pellegrino de "o Euclides da Cunha do cinema”, aquele cujas obras passavam pelo calcanhar do nacionalismo e alumiavam fraçóes da identidade nacional, ao passo também em que eram eclipsadas pelas ambivalências do pensamento euclidiano. Contudo, a sombra de Os sertóes continuou ativa - como o som de um baixo profundo - nos campos da literatura e do cinema brasileiro, notadamente no programa inicial do Cinema Novo e na incontornável "trilogia da fome": Vidas Secas, Os Fuzis e Deus e o Diabo na Terra do Sol.

Um exemplo menos evidente, porém literalmente fundamental, de retomada de $O s$ Sertóes é Carandiru, lançado em 2003. Nesse filme, o livro de Euclides funciona como um solo seco no qual o diretor Hector Babenco estrutura o conteúdo social do enredo, cujo desenvolvimento dramático segue, subterraneamente, o arranjo sequencial do livro de Euclides da Cunha. Vejamos, então, num rápido parêntese: o prólogo do filme enfatiza o ambiente do presídio, sua Terra, digamos assim, onde se tornam visíveis os martírios seculares nas selas-taperas-de-concreto que constituem uma favela institucional. Em grande plano geral, Babenco abre a narrativa com uma lenta tomada zenital da regiáo do presídio, aludindo, portanto, à visão telescópica da abertura de Os Sertóes, com a qual Euclides analisa o que chama de "Planalto Central do País (sic)" e para o qual dirige o olhar do leitor. Em seguida, a câmera executa um zoom análogo ao "efeito ótico" da aproximação que o texto euclidiano faz de Canudos, exceto que aqui nosso olhar "mergulha" na Casa de Detenção. Em fundo escuro, surge o título, Carandiru, em caracteres que fundem os traços riscados do grafite urbano e a estética naïf das capas dos cordéis nordestinos. Como no texto de Euclides, esse primeiro movimento funciona como uma matriz que gera os escóis narrativos que serão ampliados, por afinidades ou conflitos grupais, mais adiante. No desenvolvimento da trama, o segundo segmento do filme se detém mais na compreensão do Homem presidiário, suas trajetórias pregressas, interações ético-sociais 
e afetivas, seus dilemas e conflitos subjetivos, seu "isolamento" naquela terra incógnita e, em flashbacks, fora dela. Se Euclides investe numa tipologia antropológica dos personagens do sertão baiano, sobretudo em sua tentativa de explicar o surgimento étnico dos sertanejos, da violência dos jagunços e coronéis e do banditismo social dos cangaceiros, além da truculência do Estado republicano, Babenco procura conectar essa violência social do século 19, traçada em Os Sertóes, aos desdobramentos da violência atual, seja nas vidas dos criminosos, propriamente ditos, quanto na repressáo oficial, como parte do devir nacional nas metrópoles modernas. Então surge, nas sequências finais, a explosão da Luta e a ferocidade desenfreada, quando a polícia paulista invade o povoado de pedra e aço para debelar a insurreição, culminando no holocausto de 111 presos, em 2 de outubro de 1992. Como Euclides mapeia as origens históricas do conflito cotejando a Guerra de Canudos à Revolta da Vendéia francesa e, numa analogia classicizante, à lendária Tróia da Ilíada homérica, Babenco aproxima Carandiru à Vendéia Brasileira e à Tróia de Taipa do épico euclidiano. Há outras aproximaçóes possíveis: tanto no caso de Canudos quanto no de Carandiru, o Estado-Naçáo, essa racionalização da identidade nacional, utiliza-se da força militar para jugular uma sublevação de excluídos; outra analogia imediata está no lócus enunciativo, o "ponto de vista externo", tanto do médico-narrador do livro que inspirou o diretor, Estação Carandiru, o best-seller prisional de Drauzio Varella, quanto na voz do jornalista e engenheiro militar de Os Sertóes. Ambos, o doutor pop do Fantástico e o popular doutor Euclides, tiveram que enfrentar seus fantasmas, revendo in loco suas hipóteses de classe diante de duas tragédias nacionais e ao longo da convivência com sujeitos enclausurados em dois guetos sitiados. Ambos terminam seus dramas catarticamente desorientados diante das incoerências entre as certezas de suas crenças anteriores e o absurdo daquilo que testemunharam. Do ponto de vista da poética fílmica, a sequência na qual o médico de Carandiru vê-se na incômoda iminência de ter que passar uma noite no presídio, enquanto tenta encontrar, sob os olhares ameaçadores dos detentos, uma saída nos corredores sombrios, procura situar o espectador-modelo, as audiências externas em "silêncio sorridente diante da chacina", no lugar subjetivo do personagem-narrador, acentuando a clausura claustrofóbica e paranoica vivida por ele: quem são esses estranhos que nos olham e nos ameaçam de suas selas? Em qual situação de guerra silenciosa, eles, os detentos, e nós, os de fora, se encontram? Quem são os bárbaros? Quem são os civilizados? Vicariamente, nos arranjos narrativos e simulaçôes de pontos de vista dessa sequência, vive-se uma estranha sensação de alteridade que ilumina fraçóes sombrias e falhas geologicas que fendem a comunidade imaginada nacional. A coda final de Carandiru - as imagens da implosão do presídio paulista em 2002 - é uma citação indireta porém suficientemente eloquente ao desfecho incendiário da comunidade de Canudos, quando 
do fim do conflito em 1897. Tal paralelo entre um fato traumático de fins do século $19 \mathrm{e}$ um massacre em massa próximo ao centenário da Guerra de Canudos, na capital paulista, é quase uma sugestão didática: a violência perpetrada pelo Estado contra aquele povoado nordestino retorna, como uma espécie de carma da história nacional, todas as vezes que as forças repressoras oficiais são acionadas para erradicar vidas "não lamentáveis" da nação.

\section{Conclusão: “o sertão vem?” Vinha o mar.....}

Retornando ao sertão glauberiano... Os diálogos entre Glauber e Euclides da Cunha dizem das várias possibilidades de relacionamentos entre cinema e literatura, que vão além das adaptaçôes mais literais e compulsivamente "fiéis". Sobre as relaçôes intersemióticas de Os Sertóes e Deus e o Diabo na Terra do sol, Norma Pontes escreveu: "De Euclides da Cunha, Glauber Rocha não só absorve certas aproximaçóes temáticas como, por exemplo, a semelhança entre a figura-tema do Beato Sebastião e de Antonio Conselheiro", mas a tonalidade operística e épica que se apresenta mixada com o olhar do estudo crítico. "Assim, como Euclides da Cunha, Glauber Rocha tenta elaborar panoramas amplos, tenta estudar as origens sociais, místicas e políticas do cangaço e do beatismo no grande sertáo baiano". (apud CITELLI, 1996, p. 123). Mesmo que Glauber incorpore em seu filme outras referências, como a estrutura do cordel, a iconografia do gênero western americano e a montagem do cinema moderno, não há dúvida que Deus e o Diabo participa da mesma formaçáo discursiva e imagética do sertão nordestino iniciada por Os Sertóes: a seca, "o martírio secular da terra", o cangaço, o misticismo, os conflitos sociais, o crime de encomenda, a revolta pela violência, o ambiente expulsivo do sertanejo, que encontrará, na figura do vaqueiro Manuel, a superação dialética da alienação na passagem teleológica para a conscientização política, como sugere a imagem do mar que inunda o sertão no final do filme. Nesse momento, entre o mito e a história, Glauber realiza a utopia contida na frase atribuída por Euclides às profecias de Conselheiro: "O sertão vai virar mar e o mar virar sertão". Lúcia Nagib (2006, p. 28) afirma que a ligaçâo da profecia do sertão que vira mar, atribuída a Antônio Conselheiro, "se lastreia em duas fontes: a tradição oral nordestina e Os Sertóes, de Euclides da Cunha. [...] Mas a ideia grandiosa do mar parece ter exercido atração enquanto possibilidade utópica também para Euclides". Em Revolução do Cinema Novo (ROCHA, 2004, p. 285), o cineasta coloca o Cinema Novo como um momento-chave de interpretação da modernidade brasileira: "o Kinema Novo [assim mesmo segundo a grafia grega, que significa movimento] é a síntese da literatura, do teatro, da música, da pintura e da política brasileira a partir das rupturas de 1922 que impuseram aos inte- 
lectuais e artistas o repensar a prática revolucionária”. No mesmo artigo, Glauber Rocha inclui Euclides da Cunha no paideuma cinemanovista dos autores que representam "o máximo da produção ficcional brasileira” e escreveram as "estórias secretas da História, abrindo as chagas do Brasil".

A metáfora náutica de Silviano Santiago nos guiou até aqui num passeio a esse outro farol da interpretação do país que é a obra de Glauber Rocha. A imagem sugerida por Silviano Santiago, o farol com seu pulso de claridade a iluminar certas rotas de cabotagem à nação, reverbera um passeio ao farol de Virgínia Woolf. Nesse romance sobre a corrosão do tempo ambientado nas Ilhas Hébridas, Woolf faz do passeio ao farol uma ação em compasso de espera, cuja concretização é um desejo adiado pelo mal tempo de um presente irredutível, demanda somente efetivada no porvir, como costumam ser as aspiraçóes da identidade nacional. $\mathrm{O}$ farol se constitui, portanto, numa imagem da resistência ao caos-mundo e do inacabamento das identidades. Seguramente, o corpo giratório do Farol Glauber Rocha é uma referência aos viajantes-intérpretes que podem seguir os fachos em movimento dessa rocha que voa e ainda hoje é capaz de lançar outras visóes das coisas grandes e pequenas/ que nos formaram e estão a formar a sociedade brazyleyra.

\section{$\operatorname{son} 2$}

\section{NOTAS}

1 Os Sertóes, de Euclides da Cunha; Raizes do Brasil, de Sérgio Buarque de Hollanda; Retrato do Brasil, de Paulo Prado; Formação da Literatura no Brasil, Antonio Candido; Casa-Grande \& Senzala, Sobrados e Mucambos e Ordem e Progresso, de Gilberto Freyre.

2 Jorge Drexler, CD 12 Segundos de Oscuridad (Morganbritos, 2006). "Jorge Drexler, nascido em Montevidéu e residente na Espanha há mais de dez anos, tornou-se um símbolo da produçâo cultural nacional após ser o primeiro uruguaio a obter um Oscar, pela sua participaçáo no filme Diários de Motocicleta. Para além deste acontecimento concreto, podemos observar na trajetória profissional e na produção artística do compositor, uma preocupação pela construção de identidades locais e nacional que não dependem unicamente de pertencimentos territoriais, mas que não desconhecem as particularidades regionais próprias dos contextos translocais" (BÁLSAMO in SEYFERTH et al., 2007, p. 386).

3 Refiro-me ao documentário imperdível dirigido Eduardo Mocarzel e Willem Dias, Cinema de Guerrilha (2010), sobre um coletivo de jovens realizadores das periferias paulistas que se deslocam em uma kombi através dos bairros da capital paulista realizando oficinas de linguagem e produção cinematográficas, com equipamentos portáteis e ideias na cabeça.

4 Em 1987, o grande Joaquim Pedro de Andrade respondeu ao Libération de Paris: Pourquoi filmezvous? A resposta foi musicada por Adriana Calcanhoto, em A Fábrica do poema: "Para chatear os 
imbecis/ Para não ser aplaudido depois de sequências dó-de-peito/ Para viver à beira do abismo/ Para correr o risco de ser desmascarado pelo grande público/ Para que conhecidos e desconhecidos se deliciem/ Para que os justos e os bons ganhem dinheiro, sobretudo eu mesmo/ Porque, de outro jeito, a vida não vale a pena/ Para ver e mostrar o nunca visto, o bem e o mal, o feio e o bonito/ Porque vi Simão no Deserto/ Para insultar os arrogantes e poderosos, quando ficam como cachorros dentro d'água no escuro do cinema/ Para ser lesado em meus direitos autorais".

5 Caetano Veloso, em Verdade Tropical, afirma que "além do acervo crescente de obras brasileiras e estrangeiras, víamos magníficas exposiçóes didáticas que, se fosse ocaso, contavam com alguns quadros e esculturas de grandes artistas (Renoir, Degas, Van Gogh) a que a senhora Bardi tinha acesso por ser mulher do diretor do Museu de Arte de São Paulo. O Museu de Arte Moderna da Bahia funcionava no foyer, todo em mármore e vidros, do imenso Teatro Castro Alves, que tinha sido quase inteiramente destruído por um incêndio apenas um dia depois de inaugurado, poucos anos antes da criaçáo do museu. $\mathrm{O}$ foyer ficara intacto, mas a sala de espetáculos tinha se transformado numa enorme caverna negra de que Lina Bardi utilizou a parte correspondente do palco para criar um pequeno teatro de meia-arena onde, em sua colaboração com o diretor da Escola de Teatro, Eros Martim Gonçalves, montou-se a Opera de três tostôes, de Brecht (a tradução brasileira consagrada leva no titulo 'três vinténs', mas, na gíria baiana, diz-se de uma mulher que perdeu a virgindade que ela 'perdeu os três vinténs', e assim esse sentido de 'hímen' foi evitado optando-se por 'tostôes' como recentemente, numa nova montagem baiana optou-se por 'minréis'), e, depois, Calígula, de Camus" (VELOSO, 1997, p. 178).

\section{REFERÊNCIAS}

BENTES, Ivana. O Devorador de mitos. In: ROCHA, Glauber. Cartas ao mundo. São Paulo: Companhia das Letras, 1997.

CANDIDO, Antonio. Literatura e sociedade: estudos de teoria e história literária. São Paulo: Companhia Nacional do Livro, 1965.

CEVASCO, Maria Elisa. Para ler Raymond Williams. São Paulo: Editora Paz e Terra, 2001.

CHAUÍ, Marilena. Conformismo e resistência. São Paulo: Brasiliense, 1986.

CIPPOLINI, Marco. "Quero ser novo de novo": uma questáo de perspectivas. Revista ALCEU - v.8 n. 15 - p. 105 a 126 - jul./dez. 2007.

CITELLI, Adilson. Roteiro de leitura: Os Sertôes de Euclides da Cunha. São Paulo: Editora Ática, 1996.

CUNHA, Euclides. Os Sertôes: campanha de Canudos. In: SANTIAGO, Silviano. Intérpretes do Brasil, vol.1. Rio de Janeiro: Nova Aguilar, 2002.

FARINACCIO, Pascoal. Oswald-Glauber: arte, povo, revoluçâo. Rio de Janeiro: Editora EDUFF, 2012. HUXLEY, Aldous. Admirável mundo novo. São Paulo: Globo, 2014.

LEAL, Hermes. Orlando Senna: o homem da montanha. São Paulo: Imprensa Oficial, 2008.

NAGIB, Lucia. A utopia no cinema brasileiro: matrizes, nostalgia, distopias. São Paulo: Cosac Naify, 2006.

RISÉRIO, Antonio. Avant-garde na Bahia. São Paulo: Instituto Lina Bo e P. M. Bardi, 1995.

ROCHA, Glauber. Revolução do Cinema Novo. São Paulo: Cosac Naify, 2004.

SANTIAGO, Silviano. Intérpretes do Brasil. Rio de Janeiro: Nova Aguilar, 2002.

. Mário, Oswald e Carlos, Intérpretes do Brasil. Cadernos de Letras da UFF- Dossiê: Diálogos

Interamericanos, no 38, p. 19-34, 2009.

SARTRE, Jean-Paul. O que é a literatura? São Paulo: Ática, 2006.

SEYFERTH Giralda; POVOA NETO, Helion; ZANINI, Maria Catarina [et all.] (orgs.). Mundos em 
movimento - ensaios sobre migraçóes. Santa Maria: Editora UFSM, 2007.

VELOSO, Caetano. Verdade tropical. São Paulo: Companhia das Letras, 1997.

WILLIAMS, Raymond. Cultura. São Paulo: Paz e Terra, 1992.

. A Fração Bloomsbury. Revista Plural: Sociologia. USP, São Paulo, 6: 139-168. $1^{\circ}$ sem. 1999.

\section{Resumo}

O objetivo deste roteiro é comentar passagens de filmes e posicionamentos estéticos do cineasta-pensador Glauber Rocha. Tais fragmentos são lidos como fachos de uma "obra farol" fundamentais à hermenêutica da nacionalidade e modernidade brasileiras. Do conceito de "estrutura de sentimento" proposto por Raymond Williams, vem a hipótese de que a geração do cineasta, a "Fração da Avant-Garde Baiana", nas esquinas das décadas de 1950 e 1960, inventou dois dos mais importantes movimentos da cultura brasileira, a Tropicália e o Cinema Novo, relendo os clássicos de interpretação da nação em diálogo com as informações das vanguardas artísticas europeias. Analisam-se as conversas entre a obra glauberiana e Os Sertóes, de Euclides da Cunha, e a importância que o livro de Euclides exerceu no Bildung intelectual de Glauber Rocha.

\section{Resumen}

El objetivo de este script es comentar pasajes de películas y posiciones estéticas del cineasta y pensador Glauber. Dichos fragmentos se leen como las vigas de un "proyecto insignia" fundamental para la hermenéutica de nacionalidad brasileña y la modernidad. El concepto de "estructura de sentimiento", propuesto por Raymond Williams, es la hipótesis de que la generación de la cineasta, la "fracción del Avant-Garde Bahía" en las esquinas de los años 1950 y 1960, inventó dos de los movimientos culturales más importantes Brasil, Tropicália y el Nuevo Cine, releyendo la interpretación de la nación de los clásicos en el diálogo con la información del arte de vanguardia europea. Analiza las conversaciones entre glauberiana y Os Sertóes de Euclides da Cunha, y la importancia del libro de Euclides ejercida sobre Bildung intelectual de Glauber Rocha.

Légua \& Meia

Revista de Literatura

e Diversidade Cultural
SOUZA, Marcos Cezar Botelho de, Glauber Rocha, intérprete farol da imaginação. Légua \& Meia: Revista de literatura e diversidade cultural. Feira de Santana: UEFS, A. 14, nº 7, 2016, p 77-94.

Marco Botelho de Souza, é professor e coordenador da Área de Imagem do Curso de Comunicação Social - Rádio e TV - Departamento de Educação da Universidade do Estado da Bahia — UNEB, de Conceição do Coité, Bahia. Doutor em Literatura e Cultura pela Universidade Federal da Bahia - UFBA e membro dos Grupos de Pesquisa Literatura e Imagens: aspectos da literatura no cinema e Estudos de Produção e Recepção em Culturas e Linguagens. marcosbotelho.br@gmail.com 